\title{
IDENTIFICATION OF THERAPY PROFILE AND FACTORS RELATED TO INCIDENCE OF PULMONARY TUBERCULOSIS IN DENPASAR-
}

\section{BALI}

\author{
Annisa Hanum ${ }^{1 *}$, Made Krisna Adi Jaya ${ }^{2}$, I Made Bakta ${ }^{1}$ \\ ${ }^{1}$ Clinical Pharmacy Department, Universitas Bali Internasional, Bali-Indonesia \\ ${ }^{2}$ Department of Pharmacy, Faculty of Math and Science, Udayana University, Bali, Indonesia \\ Corresponding author email: annisahanumsirat58@gmail.com
}

\begin{abstract}
Background: Tuberculosis is a problem for millions of people around the world. Indonesia as the second biggest country with the highest number of Pulmonary Tuberculosis that treatment has improved gradually. Denpasar is a city with the highest sufferers in Bali. It's caused by the high rate of population, dense human settlement, and other related factors. Objective: Profiling incident and pulmonary tuberculosis treatment in Denpasar City primary health care. Methods: Observational study with cross-sectional analytic approaches. Forty pulmonary tuberculosis patients and One hundred twenty non-tuberculosis patients were observed in this study. Those were taken by multistage random sampling. Data were collected from medical records and questionnaires. A Chi-Square test was used for analyzing data. Results: Pulmonary tuberculosis sufferers are in productive ages which $65 \%$ were men. The treatment profile was excellently seen from the final treatment results of 31 people recovered and 9 people with complete treatment. Factors that have a statistical relation with pulmonary tuberculosis were occupation $(\mathrm{p}=0,012)$, income $(\mathrm{p}=0.003)$, smoking behavior $(\mathrm{p}=0.001)$, and contact history $(\mathrm{p}=0.001)$. The other factors with no relationship were education $(\mathrm{p}=0.270)$ and occupancy density $(\mathrm{p}=0.540)$. Conclusion: Pay attention to the caused factors of tuberculosis infection; society is suggested to implement a healthy lifestyle, maintain home sanitation, and environment.
\end{abstract}

Keywords: Factor Related, Pulmonary, Tuberculosis, Primary Health Care, Denpasar City

\section{INTRODUCTION}

Tuberculosis is a health problem for millions of people in the world. Indonesia is the second-highest ranked country after India ${ }^{[1]}$. Tuberculosis (TB) is an infectious disease caused by Mycobacterium tuberculosis, which can attack various organs, especially the lungs. ${ }^{[1]}$ Nearly $47 \%$ of all TB cases in Indonesia are pulmonary TB. Pulmonary $\mathrm{TB}$ is very easily transmitted through droplets of people infected with tuberculosis bacilli so that if the infection is not treated immediately, it can reduce patient productivity and cause death. ${ }^{[2,3]}$ Data from the health department, Denpasar City in 2018, described the largest cases of pulmonary TB in the province of Bali in the city of Denpasar, which recorded 540 cases. ${ }^{[3]}$

An epidemiological study conducted in the city of Denpasar primary health care showed good success rates for treatment, adherence to therapy, and cure rates, but the incidence of TB continued to increase every year. ${ }^{[4,5]}$ The TB therapy algorithm in primary health care Denpasar city has been carried out in accordance with government guidelines, namely the provision of 2RHZE / 4RH3 for category 1 or 2 RHZES / RHZE / 5RH3E3 for category $2 .^{[4,5]}$ Identification of factors associated 
with an increased incidence of pulmonary $\mathrm{TB}$, especially in Denpasar City primary health care has never been done, so this study aims to identify the profile of events, treatment, and factors associated with TB incidence in the Denpasar City primary health care, with hopes that this research can be initial overview in determining strategic steps to reduce the incidence of TB, especially in Denpasar City.

\section{RESEARCH METHODS}

\section{A. Study design}

This research is an observational study with a Cross-Sectional approach. The sample in this study amounted to 160 people, consisting of 40 pulmonary TB patients and 120 non-TB patients. Data were collected at four primary health care areas in Denpasar, including South Denpasar, West Denpasar, North Denpasar, and East Denpasar. The inclusion criteria of the research subjects were those suffering from pulmonary TB recorded in the medical records and diagnosed with non-HIV pulmonary $\mathrm{TB}$ over the age of 14 years.

\section{B. Study Instrument}

The tools used in the study were patient medical records, questionnaires, and checklist forms, divided into respondent data forms, smoking behavior questionnaires, contact history questionnaires, environmental component observation questionnaires, and TB patient treatment profile forms at the Denpasar primary health care.

\section{Data collection}

Sampling was done by a multistage random sampling technique. Data collection by questionnaire aimed to explore information related to factors related to the incidence of pulmonary TB, including education, employment, income, smoking behavior, contact history, and occupancy density. Besides, data collection is done by looking at medical records; it aims to find out the name, age, gender, address, treatment, and the end result of patient treatment.

\section{Data analysis}

In this study, data were analyzed by descriptive and non-parametric analytic methods. Descriptive analysis was performed to determine the treatment profile of pulmonary TB patients, while the nonparametric analysis was carried out to see the factors associated with the incidence of pulmonary TB in Denpasar City.

\section{RESULTS}

The results of the analysis of all variables are presented in the following tables. Table 1 shows the relationship between education level and TB incidence.

The analysis shows that there is no relationship between education and the incidence of pulmonary TB. Although statistical education has no relationship with the incidence of pulmonary TB but pulmonary TB sufferers have a tendency to have low education.

Table 1. Respondent Data Based on Education

\begin{tabular}{|c|c|c|c|c|c|c|c|}
\hline \multirow{3}{*}{ Education Level } & \multicolumn{6}{|c|}{ Pulmonary TB incident } & \multirow{3}{*}{ p-value } \\
\hline & \multicolumn{2}{|c|}{ Pulmonary TB } & \multicolumn{2}{|c|}{ Non TB } & \multicolumn{2}{|c|}{ Total } & \\
\hline & $\mathbf{n}$ & $\%$ & $\mathbf{n}$ & $\%$ & n & $\%$ & \\
\hline Low Education & 26 & 65.0 & 64 & 53.3 & 90 & 56.3 & \\
\hline High Education & 14 & 35.0 & 56 & 46.7 & 70 & 43.7 & 0.270 \\
\hline Total & 40 & 100.0 & 120 & 100.0 & 160 & 100.0 & \\
\hline
\end{tabular}

$\mathrm{n}=$ number of respondent 
Table 2 below shows the analysis between occupational variables and TB incidence. The results of the analysis showed significant results, where there is a relationship between work with the incidence of pulmonary TB, where respondents who were actively working were found to suffer more from TB. A person's work can affect the exposure of one disease, one of which is $\mathrm{TB}$, this is presumably because the potential for respondents to be exposed to TB infection is greater outside the home environment due to social interactions.

Table 3 shows the results that patients with pulmonary TB with low income more than patients with high income. This difference is significant. A good income allows one to try to meet their daily needs well and will also try to get good health services.

Table 4 shows the results that $62.5 \%$ of pulmonary TB sufferers have a history of smoking. The average number of cigarettes smoked per day by sufferers is ten cigarettes. One of the dangerous chemicals contained in cigarettes is lead. Each cigarette contains 0.5 micrograms of lead. If someone smokes 20 cigarettes per day means it produces ten micrograms, whereas the danger limit for lead levels in the body is 20 micrograms/day. This condition is what causes smokers have two times the potential to get lung infections compared to non-smokers. ${ }^{[2]}$

Table 2. Respondent Data Based on Occupation

\begin{tabular}{|c|c|c|c|c|c|c|c|}
\hline \multirow{3}{*}{ Occupation } & \multicolumn{6}{|c|}{ Pulmonary TB incident } & \multirow{3}{*}{ p-value } \\
\hline & \multicolumn{2}{|c|}{ Pulmonary TB } & \multicolumn{2}{|c|}{ Non TB } & \multicolumn{2}{|c|}{ Total } & \\
\hline & $\mathbf{n}$ & $\%$ & $\mathbf{n}$ & $\%$ & n & $\%$ & \\
\hline No Work & 14 & 35.0 & 18 & 15.0 & 32 & 20 & \\
\hline Work & 26 & 65.0 & 102 & 85.0 & 128 & 80 & $0.012 *$ \\
\hline Total & 40 & 100.0 & 120 & 100.0 & 160 & 100.0 & \\
\hline
\end{tabular}

$\mathrm{n}=$ number of respondents

$*=$ Statistically Significant

Table 3. Data of Respondents Based on Salary

\begin{tabular}{|c|c|c|c|c|c|c|c|}
\hline \multirow[t]{3}{*}{ Pendapatan } & \multicolumn{6}{|c|}{ Pulmonary TB incident } & \multirow{3}{*}{ p-value } \\
\hline & \multicolumn{2}{|c|}{ Pulmonary TB } & \multicolumn{2}{|c|}{ Non TB } & \multicolumn{2}{|c|}{ Total } & \\
\hline & $\mathbf{n}$ & $\%$ & $\mathbf{n}$ & $\%$ & n & $\%$ & \\
\hline Low Salary & 24 & 60.0 & 19 & 15.8 & 43 & 26.9 & \\
\hline High Salary & 16 & 40.0 & 101 & 84.2 & 117 & 73.1 & $0.003 *$ \\
\hline Total & 40 & 100.0 & 120 & 100.0 & 160 & 100.0 & \\
\hline
\end{tabular}

$\mathrm{n}=$ number of respondents

*= Statistically Significant

Table 4. Respondent Data Based on Smoking Behavior

\begin{tabular}{cccccccc}
\hline Smoker Behavior & \multicolumn{6}{c}{ Pulmonary TB incident } & \multirow{2}{*}{ p-value } \\
\cline { 2 - 7 } & \multicolumn{2}{c}{ Pulmonary TB } & \multicolumn{2}{c}{ Non TB } & \multicolumn{2}{c}{ Total } & \\
\cline { 2 - 7 } & $\mathbf{n}$ & $\mathbf{\%}$ & $\mathbf{n}$ & $\mathbf{\%}$ & $\mathbf{n}$ & $\mathbf{\%}$ & \\
\hline Smoker & 25 & 62.5 & 21 & 17.5 & 46 & 28.8 & \multirow{2}{*}{$0.001 *$} \\
Non Smoker & 15 & 37.5 & 99 & 82.5 & 114 & 71.2 & \\
\hline Total & 40 & 100.0 & 120 & 100.0 & 160 & 100.0 & \\
\hline
\end{tabular}

$\mathrm{n}=$ number of respondents

*= Statistically Significant 
The results of the analysis of the history of contact with TB patients (Table 5), the incidence of pulmonary TB showed a significant relationship ( $\mathrm{p}<0.05)$. The presence of contacts plays an important role in the transmission of this disease when patients with pulmonary TB longer and often spend time with other individuals who suffer from TB so that the potential transmission of pulmonary TB disease will increase.
Table 6 showed the results of the analysis of the variable occupancy density showed no difference $(p>0.05)$. This is because the average population in Denpasar already has a fairly good residential density, where the area of the respondent's house is still proportional to the number of inhabitants so that oxygen demand is fulfilled.

Table 5. Respondent Data Based on Contact History

\begin{tabular}{|c|c|c|c|c|c|c|c|}
\hline \multirow{3}{*}{ Contact History } & \multicolumn{6}{|c|}{ Pulmonary TB incident } & \multirow{3}{*}{ p-value } \\
\hline & \multicolumn{2}{|c|}{ Pulmonary TB } & \multicolumn{2}{|c|}{ Non TB } & \multicolumn{2}{|c|}{ Total } & \\
\hline & $\mathbf{n}$ & $\%$ & $\mathbf{n}$ & $\%$ & $\mathbf{n}$ & $\%$ & \\
\hline $\begin{array}{l}\text { Have Contact His- } \\
\text { tory }\end{array}$ & 36 & 90.0 & 3 & 2.5 & 39 & 24.4 & \multirow{3}{*}{$0.001 *$} \\
\hline No Contact History & 4 & 10.0 & 117 & 97.5 & 121 & 75.6 & \\
\hline Total & 40 & 100.0 & 120 & 100.0 & 160 & 100.0 & \\
\hline
\end{tabular}

$\mathrm{n}=$ number of respondents

$*=$ Statistically Significant

Table 6. Respondent Data Based on Residential Density

\begin{tabular}{|c|c|c|c|c|c|c|c|}
\hline \multirow{3}{*}{ Residential Density } & \multicolumn{6}{|c|}{ Pulmonary TB incident } & \multirow{3}{*}{ p-value } \\
\hline & \multicolumn{2}{|c|}{ Pulmonary TB } & \multicolumn{2}{|c|}{ Non TB } & \multicolumn{2}{|c|}{ Total } & \\
\hline & $\mathbf{n}$ & $\%$ & $\mathbf{n}$ & $\%$ & n & $\%$ & \\
\hline Unqualified & 13 & 32.5 & 31 & 25.8 & 44 & 27.5 & \\
\hline Qualified & 27 & 67.5 & 89 & 74.2 & 116 & 72.5 & 0.540 \\
\hline Total & 40 & 100.0 & 120 & 100.0 & 160 & 100.0 & \\
\hline
\end{tabular}

$\mathrm{n}=$ number of respondents

Table 7. Treatment Profile of Pulmonary TB Patients

\begin{tabular}{|c|c|c|}
\hline Category & $\mathbf{n}$ & $\%$ \\
\hline \multicolumn{3}{|l|}{ OAT Guideline } \\
\hline Category 1 & 40 & 100 \\
\hline Category 2 & 0 & 0 \\
\hline \multicolumn{3}{|l|}{ Dose of OAT Base on OAT Guideline } \\
\hline I.P: 2 tablet 4 CD, E.P: 2 tablet $2 \mathrm{CD}$ & 2 & 5,0 \\
\hline I.P: 3 tablet 4 CD, E.P: 3 tablet $2 \mathrm{CD}$ & 29 & 72,5 \\
\hline I.P: 4 tablet 4 CD, E.P: 4 tablet $2 \mathrm{CD}$ & 9 & 22,5 \\
\hline I.P: 5 tablet 4 CD, E.P: 5 tablet $2 \mathrm{CD}$ & 0 & 0 \\
\hline \multicolumn{3}{|l|}{ Treatment Duration } \\
\hline 6 Month & 40 & 100 \\
\hline$>6$ Month & 0 & 0 \\
\hline \multicolumn{3}{|l|}{ Treatment Result } \\
\hline Recover & 31 & 100 \\
\hline Not Recover & 0 & 0 \\
\hline Completed Therapy & 9 & 100 \\
\hline Uncompleted Therapy & 0 & 0 \\
\hline
\end{tabular}

OAT: Oral Anti Tuberculosis; CD : Combination Dosage; I.P : Initial Phase every day during 56 days RHZE (150/75/400/275); E.P: Extension Phase 3 times a week during 16 week RH (150/150); RHZE: Rifampin (R), Isoniazid (H), Pyrazinamide (Z), Ethambutol (E). 
Table 7 showed the amount of Oral Anti Tuberculosis (OAT) given already has a dose that is appropriate to the patient's body weight. The duration of treatment is also appropriate (6 months), with the final results of treatment cured or complete treatment. All patients stated that they had a record of taking medication during TB treatment. These results illustrate that Denpasar's primary health care performed well, and patients were cooperative in carrying out the therapy

\section{DISCUSSION}

Based on the analysis of educational variables, there is literature that states that pulmonary TB generally attacks most groups with low education. ${ }^{[10]}$ In this study did not affect the incidence of TB in Denpasar Health Center, this is not absolute because it could have been exposed to pulmonary TB patients by factors other than educational factors.

Analysis of occupancy variables, the results of this study were in accordance with research conducted by Nurkumalasari et al (2016), where someone with high mobility such as farmers, drivers, pedicab drivers and motorcycle taxi drivers where the likelihood of being exposed to TB is greater because of having more social interactions extensive. ${ }^{[6]}$ Therefore, it is highly recommended to avoid contact with someone suspected of being infected with pulmonary TB.

Analysis of variable salary amounts in this study was in line with research conducted by Nurhanan (2010), which states that there is a relationship between low income and the incidence of pulmonary tuberculosis. Low income can be an indirect cause of pulmonary TB events such as the fulfillment of inappropriate family nutrition, unhealthy housing conditions, and the ability to access health services also decreases. $^{[11]}$

Analysis of smoking history variables showed a relationship between smoking and the potential for lung $\mathrm{TB}$ infection.
Smoking increases the risk of TB 2-3 times, and it is associated with poor TB treatment outcomes. A prospective study, conducted in China in 2017, said that smoking is a risk factor for tuberculosis infection, biological explanations including impaired clearance of mucosal secretions, reduced phagocytic ability of alveolar macrophages, and decreased immune response and / or CD4 + lymphopenia due to nicotine in cigarettes. ${ }^{[12]}$ When TB treatment should be stopped smoking behavior because it will affect the treatment carried out. ${ }^{[13]}$

Analysis of previous contact history variables with TB patients showed significantly different results. TB bacteria are in the air/droplet when someone with TB coughs or sneezes, which allows the closest person to breathe and then infect. This study is in line with Jumriana's study (2012) that there is a relationship between contact history and the incidence of TB $(\mathrm{p}=0.023)$, patients do not realize that behavior that does not close their mouth when coughing and does not expel their phlegm in a special place of saliva will increase the risk of transmission. to others. ${ }^{[14]}$

Analysis of occupancy density variables showed results that were not significantly different. The results of this study are not in line with research conducted by Jumriana (2012) which states that statistically there is a relationship between the density of occupancy and the incidence of TB, because on average in one house inhabited by several family heads so that their homes are considered ineligible because not comparable between the floor area of the house with the number of occupants. ${ }^{[14]}$ Based on the results of this study, there was no relationship between the density of occupancy with the incidence of TB because TB transmission originated more from the contact history of colleagues and neighbors, not from families who live in one house.

Patients undergoing TB therapy stated that they received support and motivation from the family while taking TB treatment. 
The family can support the patient to recover so that the impact on patient compliance in taking medication. This is consistent with research conducted by Firdaus (2012) that a supervisor took medicine as a strong influence on the success of pulmonary TB treatment. ${ }^{[15]}$

\section{CONCLUSION}

The treatment profile of pulmonary $\mathrm{TB}$ respondents was in accordance with the National Guidelines for the Control of Tuberculosis, both in terms of OAT alloys, the amount of OAT given, and the length of treatment. Factors associated with the incidence of pulmonary TB in the Denpasar City Health Center are work, income, smoking behavior, and contact history.

\section{CONFLICT OF INTEREST}

This paper was written independently. All authors disclose no financial or personal relationships with other people or organizations that could inappropriately influence the work.

\section{ACKNOWLEDGEMENT}

We thank to lecturers and staff in department of Pharmacy, Universitas Bali Internasional and department of Pharmacy, Faculty of Math and Science, Udayana University, Bali Indonesia for the support in the implementation of research.

\section{REFERENCES}

1. Padila. Asuhan Keperawatan Penyakit Dalam. Jakarta: Nuha Medika; 2013.

2. Kementerian Kesehatan Republik Indonesia. Pedoman Nasional Pengendalian Tuberkulosis. Jakarta: Kemenkes RI; 2014.

3. Najmah. Epidemiologi Penyakit Menular. Jakarta: Trans Info Media; 2016

4. Dinas Kesehatan Kota Denpasar. Laporan Tahunan Kegiatan Program P2TB. Denpasar: Dinkes Kota Denpasar; 2018.

5. Riset Kesehatan Dasar. Laporan Hasil
Riset Kesehatan Dasar Indonesia Tahun 2017. Jakarta: Departemen Kesehatan RI; 2018.

6. Nurkumalasari, Wahyuni D, Ningsih N. Hubungan Karakteristik Penderita Tuberkulosis Paru Dengan Hasil Pemeriksaan Dahak Di Kabupaten Ogan Ilir. Jurnal Keperawatan Sriwijaya.2016; 3 (2):51-58.

7. Fatmah. Respon Imunitas Rendah Pada Usia Lanjut. Departemen Gizi Kesehatan Masyarakat. Jakarta: Universitas Indonesia Press; 2016.

8. Korua E.S., Kapantow N.H., Kawatu P.A.T., Hubungan Antara Umur, Jenis Kelamin, dan Kepadatan Hunian Dengan Kejadian TB Paru pada Pasien Rawat Jalan di Rumah Sakit Umum Daerah Nonongan, Skripsi. Manado : Fakultas Kesehatan Masyarakat Universitas Sam Ratulangi; 2014.

9. Lesley, D. 2015. Sex, gender, and health: the need for a new approach. BMJ.2001; 323 (1) : 1061-1063

10. Depkes RI. Laporan Hasil Riset Kesehatan Dasar Indonesia Tahun 2016. Jakarta: Departemen Kesehatan RI; 2017.

11. Nurhanan, M.H.P. Faktor-Faktor Yang Mempengaruhi Kejadian TB Paru dan Upaya Penanggulangannya. Jurnal Ekologi Kesehatan. 2010; 9 (4): 13401346.

12. Narasimhan, P. Risk Factors for Tuberculosis. Plumonaly Medicine. 2013; 8 (1):829-939.

13. Silva DR, Torrico MM, Duarte R, Galvão T, Bonini $\mathrm{EH}$, Arbex FF, et al. Risk Factors for Tuberculosis: Diabetes, Smoking, Alcohol Use, and the Use of Other Drugs. J Bras Pneumol. 2018;44(2):145-152

14. Jumriana. Faktor-Faktor Yang Berhubungan Dengan Kejadian Tuberkulosis Paru Di Wilayah Kerja Puskesmas Maccini Sawah Kota Makassar, Skripsi. Makasar: Fakultas Ilmu Kesehatan Universitas Islam Negeri Alauddin; 2012. 
15. Firdaus K.M., Pengaruh Peranan Pengawas Menelan Obat (PMO) Terhadap Keberhasilan Pengobatan TB Paru Di Wilayah Kerja Puskesmas Baki Sukoharjo, Skripsi. Surakarta: Fakultas Ilmu Kesehatan Muhammadiyah; 2012. 